\title{
Partial nutrient characterization of arugula (rocket - Eruca sativa L.) and the effect of heat treatment on its lipoxidase activity
}

\author{
Caracterização parcial de nutrientes da rúcula (Eruca sativa L.) e o efeito do \\ tratamento térmico sobre a atividade de lipoxidase
}

\author{
Érika Maria Marcondes Tassi ${ }^{1 *}$, Renata Maria Teixeira Duarte ${ }^{2}$, Jaime Amaya-Farfan ${ }^{3}$ \\ 1 Universidade Federal de Uberlândia (UFU), Faculdade de Medicina-Nutrição, Uberlândia/MG - Brasil \\ ${ }^{2}$ Universidade Estadual de Campinas (UNICAMP), Centro Pluridisciplinar de Pesquisas Químicas, Biológicas e Agrícolas (CPQBA), Campinas/SP - Brasil \\ ${ }^{3}$ Universidade Estadual de Campinas (UNICAMP), Departamento de Alimentos e Nutrição (DEPAN), Campinas/SP - Brasil
}

\section{*Corresponding Author}

Érika Maria Marcondes Tassi, Universidade Federal de Uberlândia (UFU), Faculdade de Medicina, Curso de Nutrição, Av. Pará, 1720, CEP: 38400-902, Uberlândia/MG - Brasil, e-mail: erikatassi@gmail.com

Cite as: Partial nutrient characterization of arugula (rocket - Eruca sativa L.) and the effect of heat treatment on its lipoxidase activity. Braz. J. Food Technol., v. 21, e2017024, 2018.

Received: Apr. 18, 2017; Accepted: Nov. 23, 2017

\section{Abstract}

The objective of this work was to determine some key nutrients in arugula (or rocket) and the effect of heat treatment on its lipoxidase activity. The protein, lipid, carbohydrate, fibre, ash, fatty acid composition, $\alpha$-tocopherol and carotenoid contents were determined. Due to its importance in lipid degradation, the lipoxidase activity was measured in the raw and cooked leaves. The composition was (\% fresh mass): 2.5 protein, 0.3 lipids, 4.1 carbohydrates, 1.3 fibre and 1.8 ash. The lipid phase contained $6.2 \mathrm{mg}$ of $\alpha$-tocopherol, $5.3 \mathrm{mg}$ of lutein and $3.2 \mathrm{mg}$ of $\beta$-carotene. Arugula was found to be rich in $\alpha$-linolenic acid ( $48 \%$ of the oil). The heat treatment was not sufficient to totally inactivate the lipoxidase activity.

Keywords: $\omega-3$ fatty acid; Eruca sativa L.; Green leafy vegetables; Lipoxidase.

\section{Resumo}

O objetivo deste trabalho foi determinar alguns nutrientes essenciais da rúcula e o efeito do tratamento térmico na atividade da lipoxidase. Foram, assim, determinados: proteínas, lipídios, carboidratos, fibras, cinzas, composição de ácidos graxos, $\alpha$-tocoferol e carotenoides. Devido à sua importância na degradação lipídica, a atividade da lipoxidase foi medida em folhas cruas e cozidas. A composição foi (\% massa fresca): 2,5 proteína; 0,3 lipídeos; 4,1 carboidratos; 1,3 fibra; 1,8 cinzas. A fase lipídica continha 6,2 mg de $\alpha$-tocoferol, 5,3 mg de luteína e 3,2 mg de $\beta$-caroteno. Verificou-se que a rúcula é rica em ácido $\alpha$-linolênico (48\% de óleo). O tratamento térmico não foi suficiente para inativar totalmente a atividade da lipoxidase.

Palavras-chave: Ácido graxo $\omega-3$; Eruca sativa L.; Folhas verdes; Lipoxidase.

\section{Introduction}

Various epidemiological studies have shown that the consumption of fruits and vegetables is associated with a decrease in the risk of some serious chronic diseases, considered to be one of the predominant public health hazards (NGUYEN et al., 2016; LIU et al., 2016; VAINIO; WEIDERPASS, 2006; RODRIGUEZ-AMAYA, 2016a). It is believed that the protective effect against cancer is due to the various forms of antioxidant action of some of the nutrients, such as the carotenoids present in the foods.
Carotenoids are widespread natural pigments responsible for the yellow, orange and red colours of fruits, flowers, tubers, fish, birds and invertebrates, which act in protecting human tissues against the damaging effects of radiation. Chemically, they are hydrocarbons generally containing 40 carbons and showing a polyenic structure with alternating double bonds responsible for their capacity to absorb light, particularly in the blue region. This variety of structures, that can also contain oxygen, endow the carotenoids with their antioxidant properties 
for the inactivation of free radicals and sequester of the most reactive form of oxygen, which is singlet oxygen (ALONSO-ALVAREZ et al., 2004; RODRIGUEZ-AMAYA, 2016b).

Leafy vegetables are considered to be good sources of carotenoids, including lutein, which, amongst other functions, acts against the degeneration of macular tissue (GRANADO et al., 2003), and $\beta$-carotene, the principal carotene showing provitamin A activity. However, the amounts of these bioactive compounds with potential health benefits present in the leaf may decrease in the presence and action of the enzyme lipoxidase, due to its involvement in the degradation of these compounds.

Arugula (also known as rocket) (Eruca sativa) is a widely consumed vegetable in Brazil, especially in the southern and southeastern regions of the country. The irregular, wide leafed Brazilian cultivar is a herbaceous Brasicaceae vegetable, with a low stature and annual periodicity. This vegetable is also found in southern Europe and western Asia, where the string-like narrow leaf cultivars are more common (AGUIAR et al., 2014). It is mostly consumed raw as in salads, but is also served in other fashionable dishes such as pizzas and spaghetti sauce. Its leaves are tender, with a characteristic mildly pungent hot taste, readily destroyed by the heat treatment.

Recent studies have unveiled the presence of health promoting substances such as antioxidative polyphenols (HEIMLER et al., 2007) and antigenotoxic glucosinolates (erucin and erysolin) (LAMY et al., 2008). Using rats, Alqasoumi (2010) observed that the ethanolic extract of Eruca sativa L. protects the liver against carbon tetrachloride injury.

The aim of the present work was to study the composition of arugula as a representative of the leafy vegetables, especially considering its protein, fibre, carotenoid, tocopherol and fatty acid contents. The activity of lipoxidase in the raw and cooked leaves was also monitored due to its potential impact on nutrient degradation, including the carotenoids.

\section{Material and methods}

\subsection{Sampling}

The arugula was acquired from two local outlets (Campinas, SP, Brazil), the post-harvest time being 24 hours. Ten bunches were used (cleaned and dried at room temperature), and $4 \mathrm{~cm}$ of the stalks were separated.

\subsection{Composition}

Dietary fibre was determined by the enzymatic method based on the Asp et al. (1983) technique, modified according to the AOAC recommendations (DEE et al., 1992). Total protein was determined both by the semi-micro-Kjeldahl and biuret methods (HELRICH, 1990), and total lipids by the Bligh and Dyer (1959) method. The ash and moisture contents were determined by incineration at $550{ }^{\circ} \mathrm{C}$ (HORWITZ, 1980) and by weighing after oven drying at $105^{\circ} \mathrm{C}$ (HORWITZ, 1980), respectively. The carbohydrate content was calculated by difference.

\subsection{Tocopherols}

Leaves prepared as described above were weighed in the fresh state, freeze-dried, forced through sieves (60 mesh) and homogenized. The lipid fraction was extracted according to Bligh and Dyer (1959) by placing $3 \mathrm{~g}$ of freeze-dried samples in $80 \mathrm{~mL}$ tubes and adding $20 \mathrm{~mL}$ chloroform and $8 \mathrm{~mL}$ distilled water. This mixture was homogenized in a rotary blender for $30 \mathrm{~min}$. A further $10 \mathrm{~mL}$ chloroform and $10 \mathrm{~mL}$ of a $1.5 \%$ sodium sulphate solution were then added and shaken vigorously for $2 \mathrm{~min}$. This mixture was centrifuged to separate the layers and the organic matter in the chloroform layer separated, filtered and evaporated in a $\mathrm{N}_{2}$ jet. The residue was suspended in $100 \mu \mathrm{L}$ of chromatographic grade methanol and filtered, before injection into a chromatograph (Varian 9012), equipped with a C-18 column (LiChospher 100RP-18, Merck, $5 \mu \mathrm{M}$, $125 \times 4 \mathrm{~mm}$ ), using a mobile phase of $100 \%$ methanol (isocratic mode) and a flow rate of $1 \mathrm{~mL} / \mathrm{min}$. The mobile phase was previously de-gassed by ultra-sonication. The system was monitored using a fluorescence detector (Varian 9075) with excitation at $290 \mathrm{~nm}$ and emission at $330 \mathrm{~nm}$ and the Star Chromatography Workstation software. A calibration curve was constructed using $\alpha$-tocopherol (T-3001, Sigma, St. Louis, USA) as the external standard. This technique was based on the method of Sharma and Kumar (1990).

\subsection{Carotenoids}

Both high performance liquid chromatography (HPLC) and open column chromatography (OCC) were used, the latter being carried out according to Rodriguez et al. (1976), with the particular purpose of obtaining the freshly prepared standards. A sample $(5 \mathrm{~g})$ was exhaustively homogenized in a blender with acetone $\left(5^{\circ} \mathrm{C}\right)$ and Celite, and then filtered (Whatman $\mathrm{N}^{\circ} 3$ paper). The filtrate was re-suspended in petroleum ether (Synth, a.g.) and partition carried out with water to remove the acetone. A rotary evaporator was used to concentrate the extract $\left(t<35^{\circ} \mathrm{C}\right)$ and separation carried out in an open glass column of MgO:Hyflosupercel (Merck, Darmstadt, 1:1, the mixture being previously activated at $110^{\circ} \mathrm{C}$ for 2 hours). The polarity of the mobile phase was gradually adjusted according to the polarity of the carotenoid under elution, sequentially yielding the following four well defined bands: neoxanthin (light yellow; $60 \%$ to $70 \%$ acetone in petroleum ether), lutein (medium-dark yellow; $15-18 \%$ acetone in petroleum ether), violaxanthin (light yellow; 25\% to $40 \%$ acetone in petroleum ether) and $\beta$-carotene (orange; $5 \%$ ethyl ether in petroleum ether). 
Schematically, the entire procedure can be depicted as follows: Acetone $\left(5^{\circ} \mathrm{C}\right)+$ sample $(5 \mathrm{~g}) \rightarrow$ Homogenize in an explosion-proof blender $\rightarrow$ Filter until stationary phase appears colourless $\rightarrow$ Transfer pigment to petroleum ether $\rightarrow$ Wash with water to complete removal of acetone $\rightarrow$ Concentrate remaining liquid in rotary evaporator $\left(\mathrm{T}<35^{\circ} \mathrm{C}\right) \rightarrow$ Separate carotenoids using an open column (MP with increasing concentrations of acetone [1\% to 15\%] in petroleum ether) $\rightarrow$ Read in a spectrophotometer (350 nm to $550 \mathrm{~nm}$ ). All operations were carried out under dimmed light and a fast hood.

After washing with water to remove the acetone, each fraction was further reduced in a rotary evaporator $\left(\mathrm{t}<35^{\circ} \mathrm{C}\right)$. The readings were taken using a spectrophotometer in the range from $350 \mathrm{~nm}$ to $550 \mathrm{~nm}$. The carotenoid concentration was calculated using the absorbance in petroleum ether (DAVIES, 1976).

HPLC was used to validate the results of the carotenoid analysis. A Waters liquid chromatograph was used (model 2690) with an automatic injector controlled by a Millennium Workstation (version 2010) and $\mathrm{C}_{18}$ reverse phase column (Spherisorb S3 ODS2, $3 \mu \mathrm{m}, 4.6 \mathrm{~mm} \times 150 \mathrm{~mm}$ ). The mobile phase was a mixture of acetonitrile:methanol:ethyl acetate with a flow rate of $0.5 \mathrm{~mL} / \mathrm{min}$ and gradient elution from 95:5:0 to $60: 20: 20$ in $20 \mathrm{~min}$, the latter being maintained up to the end of the run. Re-equilibrium back to the initial conditions took 15 minutes. A photodiode array detector was used (Waters model 996).

\subsection{Fatty acids}

Sample esterification was carried out according to the Hartman and Lago (1973) method. The fatty acids composition was determined using a Varian gas chromatograph (model 3600), equipped with a $30 \mathrm{~m} \times 0.252 \mathrm{~mm}, 0.25 \mu \mathrm{m}$ DB-WAX capillary column (liquid phase of polyethylene glycol), temperature program ( $170{ }^{\circ} \mathrm{C}-1$ min and $210^{\circ} \mathrm{C}-15 \mathrm{~min}$ ), injector (130 split) and an isothermal temperature of $250^{\circ} \mathrm{C}$. The stripping gas was $\mathrm{H}_{2}$ with a flow rate of $1.2 \mathrm{~mL} / \mathrm{min}$. A flame ionization detector (FID) with an isothermal temperature $\left(T=250^{\circ} \mathrm{C}\right)$ was used. The Star Chromatography Workstation (version 2010) was used to integrate the sample. Identification and quantification were by way of external fatty acid standards (Sigma, St. Louis, USA).

\subsection{Lipoxidase activity}

Lipoxidase activity (E.C.1.13.11.12) was determined in both the raw and cooked $\left(5,10\right.$ and 15 min at $\left.97^{\circ} \mathrm{C}\right)$ leaves according to Holman's (1955) method, using linoleic acid as the substrate. This procedure comprised the following steps: $8 \mathrm{~g}$ leaves in $100 \mathrm{~mL}$ water. Blend for $4 \mathrm{~min}$. Filter through glass wool. Filter through paper. Centrifuge for $15 \mathrm{~min}$ at $(1800 \mathrm{~g}$ ). Add $5 \mathrm{~mL}$ water to $1 \mathrm{~mL}$ of supernatant (at this stage the $\mathrm{pH}$ should be 6.5). Take $1 \mathrm{~mL}$. Add $2 \mathrm{~mL}$ substrate (linoleic acid). Read in a spectrophotometer at $234 \mathrm{~nm}$ for $4 \mathrm{~min}$.

\subsection{Data analysis}

The analyses were carried out in triplicate. Statistical analyses were carried out using one-way ANOVA and $p$-values $<0.05$ considered statistically significant. The statistical test was applied using Statistica v.5.0 (Stasoft, USA). Differences between the means were determined by the Tuckey test.

\section{Results and discussion}

\subsection{Proximate composition}

Table 1 shows the values obtained for the protein, lipid, carbohydrate, ash, fibre and moisture contents. The mean values encountered showed no marked differences from those of other leaves reported in the literature, with the exception of the total dietary fibre content, which was lower ( $50 \%)$ than the average values for other fresh leafy vegetables like watercress (Nasturtium officinale W.T. Aiton), lettuce (Lactuca sativa), basil (Ocimum basilicum $\mathrm{L}$ ) and endive (Cichorium endivia L.) (UNICAMP, 2006), but in agreement with the value cited for American arugula (USDA, 2008).

\section{$3.2 \alpha$-Tocopherol}

Due to its high analytical specificity, HPLC with fluorescence detection is well accepted for the quantification of tocopherols in foods. The use of $100 \%$ methanol as the mobile phase has already been cited in many studies (TAN; BRZUSKIEWICZ, 1989; SHARMA; KUMAR, 1990), but in foods containing other isomers besides $\alpha$-tocopherol, the use of a $60: 40 \mathrm{v} / \mathrm{v}$ acetonitrile:methanol mixture is recommended (TAN; BRZUSKIEWICZ, 1989). Since the main component of the tocopherol family found in vegetables is $\alpha$-tocopherol, a mobile phase of $100 \%$ methanol was used in the present study.

Using HPLC, Konings et al. (1996) found a value of $6.3 \mathrm{mg}$ tocopherol/100 $\mathrm{g}$ vegetable in broccolis. The mean value for the $\alpha$-tocopherol found in arugula was

Table 1. Mean proximate composition of arugula.

\begin{tabular}{cc}
\hline Compound & Composition $(\%)^{*}$ \\
\hline Protein & $2.5 \pm 0.08$ \\
Lipid & $0.3 \pm 0.04$ \\
Carbohydrate & $4.1 \pm 0.09$ \\
Fibre $^{\star \star}$ & $1.3 \pm 0.05$ \\
Ash & $1.8 \pm 0.10$ \\
Moisture & $92.0 \pm 0.20$ \\
\hline
\end{tabular}

*The values represent the mean of three determinations \pm SD (wet weight basis); ${ }^{* *}$ Total dietary fibre. 
Partial nutrient characterization of arugula (rocket - Eruca sativa L.) and the effect of heat treatment on its lipoxidase activity Tassi, E. M. M. et al.

$6.2 \mathrm{mg} / 100 \mathrm{~g}$ leaf (Table 2), differing little from the value found in broccolis. Leaves such as lettuce, watercress and spinach presented values of $0.22,0.70$ and $2.03 \mathrm{mg} / 100 \mathrm{~g}$ respectively (USDA, 2008).

Figure 1 shows the chromatogram of the $\alpha$-tocopherol present in arugula, its retention time being 4 minutes.

Table 2. $\alpha$-tocopherol and carotenoid contents of arugula, determined by HPLC and OCC.

\begin{tabular}{lcc}
\multicolumn{1}{c}{ Compound } & mg /100 g fresh leaves* \\
HPLC & OCC \\
\hline$\alpha$-tocopherol carotenoids & $6.2 \pm 0.8$ & ND \\
$\beta$-carotene & $3.5 \pm 0.9$ & $3.8 \pm 0.7$ \\
Lutein & $5.3 \pm 1.1$ & $6.3 \pm 0.9$ \\
neoxanthin & $0.9 \pm 0.2$ & $\mathrm{NS}$ \\
neoxanthin & $1.8 \pm 0.3$ & $\mathrm{NS}$ \\
neoxanthin + violaxanthin & $\mathrm{S}$ & $3.2 \pm 0.9$ \\
\hline
\end{tabular}

${ }^{*}$ Mean \pm SD of triplicates; $\mathrm{ND}=$ not determined; $\mathrm{S}=$ separated by HPLC; $N S=$ not separated by OCC.

\subsection{Carotenoids}

Currently carotenoids are more commonly determined by HPLC due to the difficulties posed by these compounds which are highly degradable, absorb light at different wavelengths and have different absorption coefficients. Despite the rapidity of HPLC, this technique still depends on open column chromatography to isolate the unstable and expensive standards from natural sources. For these reasons, the carotenoids reported in this paper were quantified by both OCC and HPLC (Figure 2). After separating the compounds by HPLC, spectra of the peaks were obtained for validation purposes.

The $\beta$-carotene and lutein contents obtained by OCC and HPLC were almost identical; however, as can be seen, OCC did not separate violaxanthin from neoxanthin (Table 2). According to the classification of Begum and Pereira (cited by RODRIGUEZ-AMAYA, 1997), which divided the leafy vegetables found in India into three groups, arugula can be considered as a vegetable with a medium $\beta$-carotene content (3.5 mg/100 g). Considering

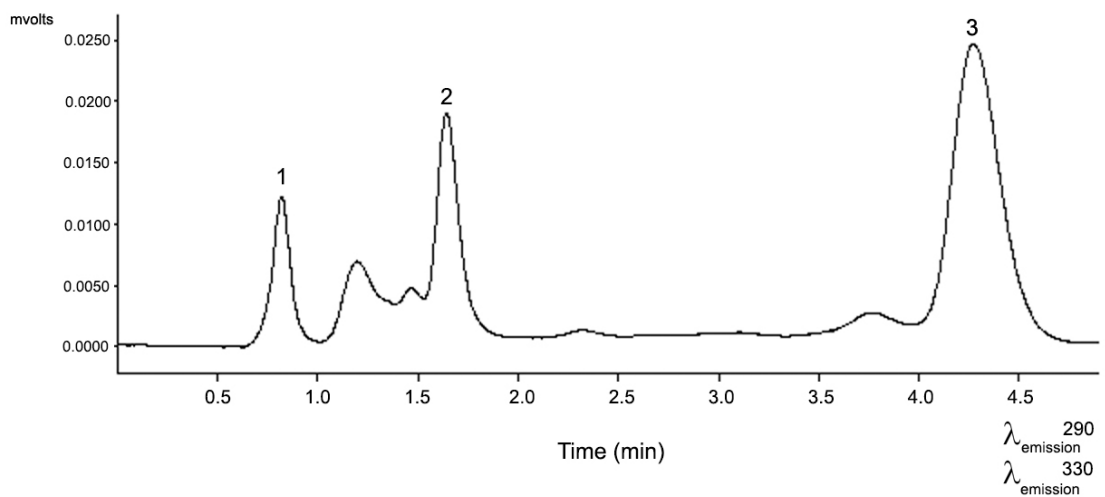

Figure 1. Chromatogram of the arugula lipid extract. Peaks 1 and 2 were not identified. Peak 3 was $\alpha$-tocopherol. The chromatographic conditions are described in the text.

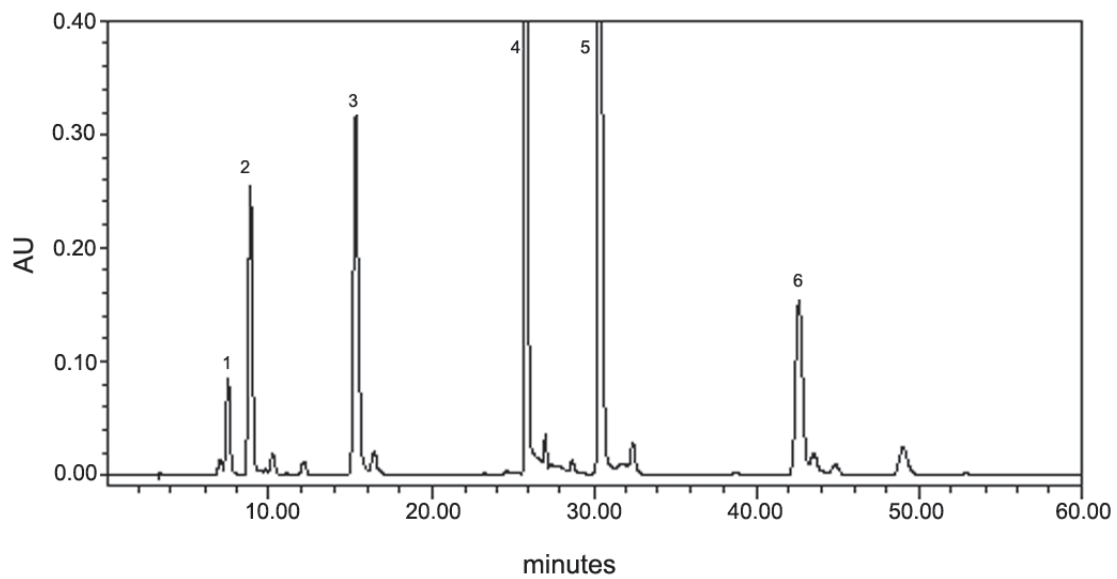

Figure 2. HPLC Chromatogram of the raw arugula extract: 1-neoxanthin, 2-violaxanthin, 3-lutein, 4,5-chlorophylls and 6- $\beta$-carotene. The chromatographic conditions are described in the text. 
that $\beta$-carotene is the carotenoid with the highest pro-vitamin $A$ activity and that the cost of arugula in Brazil is not high, or similar to the price of lettuce, the consumption of this vegetable represents a good alternative for the prevention of hypovitaminosis $A$.

An early study on the biological value of $\beta$-carotene from leaves reported that the bioavailability of the $\beta$-carotene from leafy vegetables is low, and much lower than that from synthetic $\beta$-carotene (DE PEE et al., 1995), raising doubts as to the efficacy of leafy vegetables as a source of vitamin A for man. However, a specific study on the bioavailability of the arugula carotenoids in humans showed that the absorption of the $\beta$-carotene present in raw arugula by healthy women was substantial from both raw $(\sim 48 \%)$ and blanched ( $62 \%$ ) leaves, as compared to that of synthetic $\beta$-carotene (TASSI; AMAYA-FARFÁN, 2008).

Arugula, like other leafy vegetables, also contains a large amount of lutein (5.3 mg/100 g) (Figure 2). Lutein is an oxycarotenoid (xanthophyll) that usually targets animal tissues, particularly the macula of the retina and the blood serum. Studies have shown that this pigment, together with zeaxanthin, provides protection to the sensitive retina cells, apparently against macular degeneration (GRANADO et al., 2003).

\subsection{Fatty acids}

That linolenic acid (C 18:3) represents $48 \%$ of the fatty acid composition of the arugula leaf, this being an essential fatty acid of functional importance. Studies have shown that the ingestion of this compound presents positive effects on the health, including hypocholesterolemia and anti-thrombosis and anti-inflammatory activities (KATAN et al., 1995).

Despite the fact that the presence of polyunsaturated fatty acids in arugula is positive on account of the above cited effects, on the other hand these fatty acids show the undesirable effect of rapidly deteriorating the vegetable, due to the direct action of lipoxidase on the acids, be they free or bound, forming intermediary radicals (WHITAKER, 1994).

However, the oil extracted from arugula seeds contains predominantly erucic acid (C 22:1), although the fatty acid composition of arugula seeds has been shown to vary according to the geographical location. In seeds of German origin, for instance, this acid represented $47 \%$, whereas in seeds from Israel, the percentage fell to $33 \%$ (YANIV et al., 1998). This large variation in composition is also likely to occur in the leaves, although it was not possible to reach this kind of conclusion.

\subsection{Lipoxidase activity}

There are relatively little data available on the effect of enzymes on the nutritional quality of leaves. However it is known that lipoxidase is involved in the oxidation of essential fatty acids, all of which are unsaturated, thus promoting a decrease in their nutritional value. Oxidation of the fatty acids by the direct action of lipoxidase also results in the formation of free radicals and hydroperoxides, which are responsible for the loss in colour of the vegetable and the development of rancidity, in addition to the negative effects on consumer health (BAYSAL; DEMIRDÖVEN, 2007).

Considering that the carotenoids are nutrients of importance in the human diet and the fact that they are susceptible to attack by lipoxidase (WHITAKER, 1994), the need to obtain more information on the action of this enzyme becomes apparent.

The activity of the lipoxidase present in arugula was measured after cooking the leaves at $97^{\circ} \mathrm{C}$ for 5,10 and 15 min. In order to determine any effect of the cooking procedure used. As can be seen in Figure 3, as from the first 5 min approximately $50 \%(p<0.05)$ was inactivated, but the longer cooking periods were not sufficient to

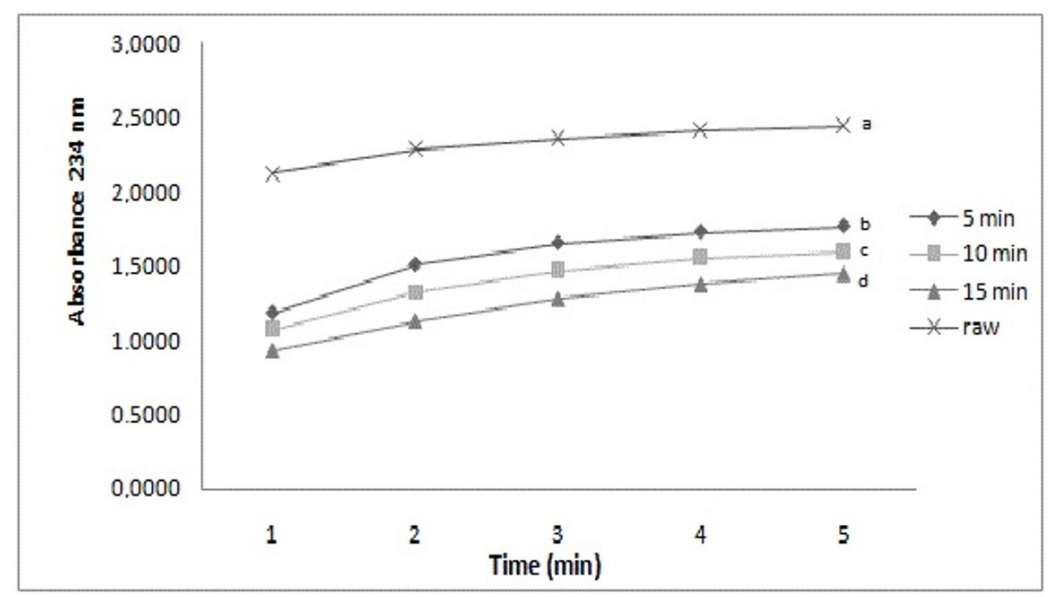

Figure 3. Lipoxidase activity in raw arugula and in arugula cooked for different times. Absorbance of the substrate linoleic acid versus reaction time. The results represent the mean of 4 determinations. 
Partial nutrient characterization of arugula (rocket - Eruca sativa L.) and the effect of heat treatment on its lipoxidase activity Tassi, E. M. M. et al.

completely inactivate the lipoxidase. No results were found in the literature consulted that could be used for comparison with these results but in a study of soybean lipoxidase, Paulo et al. (1995) reported the existence of highly heat-resistant lipoxidase isoenzymes (isoenzyme 4). Although dealing with different foods, it is likely that a similar heat-resistant isoenzyme exists in arugula.

Enzyme activity in a food can vary considerably according to the following: the cultivar, the degree of maturity and the environmental growth conditions (temperature, soil and fertilization). According to Whitaker (1994), the time taken to inactivate an enzyme depends on its concentration in the food and it is difficult to inactivate enzymes with high initial concentrations.

\section{Conclusions}

From the foregoing results it could be concluded that arugula possesses a macronutrient composition similar to that of other leafy vegetables; $\alpha$-linolenic acid was shown to be the predominant (48\%) fatty acid, the enzymatic activity of lipoxidase was reduced by $50 \%$ after 5 min cooking. The carotenoid composition of the arugula leaf agreed with published data of other leaves, but lutein (5.3 $\mathrm{mg} / 100 \mathrm{~g})$ and $\beta$-carotene $(3.5 \mathrm{mg} / 100 \mathrm{~g})$ were its major components, being present in large amounts.

\section{Acknowledgements}

The authors are grateful to CNPq and PRONEX (FINEP/MCT) for their financial support.

\section{References}

AGUIAR, A. T. E.; GONÇALVES, C.; PATERNIANI, M. E. A. G. Z.; TUCCI, M. L. S. A.; CASTRO, C. E. F. Instruções agrícolas para as principais culturas econômicas. Campinas: Instituto Agronômico, 2014. p. 362-36. (Boletim 200).

ALONSO-ALVAREZ, C.; BERTRAND, S.; DEVEVEY, G.; GAILLARD, M.; PROST, J.; FAIVRE, B.; SORCI, G. An experimental test of the dose-dependent effect of carotenoids and immune activation on sexual signals and antioxidant activity. American Naturalist, v. 164, n. 5, p. 651-659, 2004. PMid:15540154.

ALQASOUMI, S. Carbon tetrachloride-induced hepatotoxicity: protective effect of 'rocket' Eruca sativa L. in rats. The American Journal of Chinese Medicine, v. 38, n. 1, p. 75-88, 2010. http:// dx.doi.org/10.1142/S0192415X10007671. PMid:20128046.

ASP, N. G.; JOHANSSON, C. G.; HALLMER, H.; SILJESTROEM, M. Rapid enzymatic assay of insoluble and soluble dietary fiber. Journal of Agricultural and Food Chemistry, v. 31, n. 3, p. 476-482, 1983. http://dx.doi.org/10.1021/jf00117a003. PMid:6309935.
BAYSAL, T.; DEMIRDÖVEN, A. Lipoxygenase in fruits and vegetables: a review. Enzyme and Microbial Technology, v. 40, n. 4, p. 491-496, 2007. http://dx.doi.org/10.1016/j.enzmictec.2006.11.025.

BLIGH, E. G.; DYER, W. J. A rapid method of total lipid extraction and purification. Canadian Journal of Biochemistry and Physiology, v. 37, n. 8, p. 911-917, 1959. http://dx.doi.org/10.1139/ 059-099. PMid:13671378.

DAVIES, B. H. Carotenoids. In: GOODWIN, T. W. Chemistry and biochemistry of plant pigments. 2nd ed. London: Academic Press, 1976.

DE PEE, S.; WEST, C. E.; MUHILAL; KARYADI, D.; HAUTVAST, J. G. Lack of improvement in vitamin A status with increased consumption of dark-green leafy vegetables. Lancet, v. 346, n. 8967, p. 75-81, 1995. http://dx.doi.org/10.1016/S01406736(95)92111-7. PMid:7603216.

DEE, S.; PROSKY, L.; DEVRIES, J. Determination of total, soluble and insoluble dietary fiber in foods: collaborative study. Journal Association of Analytical Chemistry, v. 3, p. 234-238, 1992.

GRANADO, F.; OLMEDILLA, B.; BLANCO, I. Nutritional and clinical relevance of lutein in human health. British Journal of Nutrition, v. 90, n. 3, p. 487-502, 2003. http://dx.doi.org/10.1079/ BJN2003927. PMid:14513828.

HARTMAN, L.; LAGO, R. C. Rapid preparation of fatty acid methyl esters from lipids. Laboratory Practice, v. 22, n. 6, p. 475-476, 1973. PMid:4727126.

HEIMLER, D.; ISOLANI, L.; VIGNOLINI, P.; TOMBELLI, S.; ROMANI, A. Polyphenol content and antioxidative activity in some species of freshly consumed salads. Journal of Agricultural and Food Chemistry, v. 55, n. 5, p. 1724-1729, 2007. http:// dx.doi.org/10.1021/jf0628983. PMid:17279769.

HELRICH, K. (Ed.). Official methods of analysis of the Association of Official Analytical Chemists. 15th ed. Arlington: AOAC, 1990.

HOLMAN, R. T. Measurement of lipoxidase activity. In: GLICK, $D$. Methods biochemical analysis. New York: Interscience Publishers, 1955. p. 113-119.

HORWITZ, W. (Ed.). Official methods of analysis of the Association of Official Analytical Chemists. 13th ed. Washington: AOAC, 1980.

KATAN, M. B.; ZOCK, P. L.; MENSINK, R. P. Dietary oils, serum lipoproteins and coronary heart disease. The American Journal of Clinical Nutrition, v. 61, n. 6, p. 1368-1373, 1995. Supplement. http://dx.doi.org/10.1093/ajcn/61.6.1368S. PMid:7754989.

KONINGS, E. J. M.; ROOMANS, H. H. S.; BELJAARS, P. R. Liquid chromatographic determination of tocopherols and tocotrienols in margarine, infant foods, and vegetables. Food composition and additives. Journal of AOAC International, v. 79, p. 11291134, 1996.

LAMY, E.; SCHRÖDER, J.; PAULUS, S.; BRENK, P.; STAHL, T.; MERSCH-SUNDERMANN, V. Antigeno toxic properties of Eruca 
Partial nutrient characterization of arugula (rocket - Eruca sativa L.) and the effect of heat treatment on its lipoxidase activity Tassi, E. M. M. et al.

sativa (rocket plant), erucin and erysolin in human hepatoma (HepG2) cells towards benzo(a)pyrene and their mode of action. Food and Chemical Toxicology, v. 46, n. 7, p. 2415-2421, 2008. http://dx.doi.org/10.1016/j.fct.2008.03.022. PMid:18479797

LIU, X.; YAN, Y.; LI, F.; ZHANG, D. Fruit and vegetable consumption and the risk of depression: a meta-analysis. Nutrition, v. 32, n. 3, p. 296-302, 2016. http://dx.doi.org/10.1016/j. nut.2015.09.009. PMid:26691768.

NGUYEN, B.; BAUMAN, A.; GALE, J.; BANKS, E.; KRITHARIDES, L.; DING, D. Fruit and vegetable consumption and all-cause mortality: evidence from a large Australian cohort study. The International Journal of Behavioral Nutrition and Physical Activity, v. 13, n. 1, p. 9, 2016. http://dx.doi.org/10.1186/s12966016-0334-5. PMid:26810760.

PAULO, A. C. O. C. J.; CABRAL, L. C.; VIEIRA, C. R.; BASTOS, A. M. M. Estudo cinético da inativação térmica protéica na soja. Food Science and Technology, v. 15, p. 262-267, 1995.

RODRIGUEZ, D. B.; RAYMUNDO, L. C.; LEE, T. C.; SIMPSON, K. L.; CHICHESTER, C. O. Carotenoid pigment changes in ripening Momordica charantia fruits. Annals of Botany, v. 40, n. 3, p. 615-624, 1976. http://dx.doi.org/10.1093/oxfordjournals. aob.a085171.

RODRIGUEZ-AMAYA, D. B. Carotenoids and food preparation: the retention of provitamin A carotenoids in prepared, processed, and stored foods. Arlington: John Snow/Omni, 1997. 88 p.

RODRIGUEZ-AMAYA, D. B. Carotenoids and chronic diseases. In: RODRIGUEZ-AMAYA, D. B. Food carotenoids: chemistry, biology, and technology. Hoboken: IFT Press, 2016a. p. 282-304.

RODRIGUEZ-AMAYA, D. B. Nomenclature, structures, and physical and chemical properties. In: RODRIGUEZ-AMAYA, D. B. Food carotenoids: chemistry, biology, and technology. Hoboken: IFT Press, 2016b. p. 1-23.

SHARMA, A.; KUMAR, A. Concurrent analysis of plasma retinol and $\alpha$-Tocopherol by isocratic HPLC. Indian Journal of Experimental Biology, v. 28, n. 8, p. 780-782, 1990. PMid:2253973.

TAN, B.; BRZUSKIEWICZ, L. Separation of tocopherol and tocotrienol isomers using normal-and reverse-phase. Liquid Chomatography. Analytical Biochemistry, v. 180, n. 2, p. 368-373, 1989. http://dx.doi.org/10.1016/0003-2697(89)90447-8. PMid:2817368.

TASSI, E. M. M. T.; AMAYA-FARFÁN, J. Carotenoid uptake by human triacylglycerol rich lipoproteins from the green leafy vegetable Eruca sativa. Ecology of Food and Nutrition, v. 47, n. 1, p. 77-94, 2008. http://dx.doi.org/10.1080/03670240701641016.

UNITED STATES DEPARTMENT OF AGRICULTURE - USDA. National Nutrient Database for Standard Reference, NDB No: 11959 Nutrient values and weights are for edible portion. Washington, 2008. Release 21.

UNIVERSIDADE ESTADUAL DE CAMPINAS - UNICAMP. TACO: tabela brasileira de composição de alimentos. Versão 2. Campinas: Núcleo de Estudos e Pesquisas em Alimentação, Unicamp, 2006. $105 \mathrm{p}$

VAINIO, H.; WEIDERPASS, E. Fruit and vegetables in cancer prevention. Nutrition and Cancer, v. 54, n. 1, p. 111-142, 2006. http://dx.doi.org/10.1207/s15327914nc5401_13. PMid:16800779.

WHITAKER, J. R. Principles of enzymology for the food science. 2nd ed. New York: Marcel Dekker, 1994. 301 p.

YANIV, Z.; SCHAFFERMAN, D.; AMAR, Z. Tradition, uses and biodiversity of rocket (Eruca sativa, Brassicaceae) in Israel. Economic Botany, v. 52, n. 4, p. 394-400, 1998. http://dx.doi. org/10.1007/BF02862069. 